\title{
Growth and production of ornamental sunflower grown in the field in response to application of humic acids
}

\author{
Crescimento e produção de girassol ornamental cultivado em \\ campo em resposta à aplicação de ácidos húmicos
}

\author{
Lílian Estrela Borges Baldotto ${ }^{I^{*}}$ Marihus Altoé Baldotto ${ }^{I}$
}

\begin{abstract}
The humic acid fraction of organic matter has a stimulating effect on the growth and development of ornamental plants. This study investigated the response in growth and yield of field-grown ornamental sunflower (Helianthus annuus L.) to the seed treatment with humic acids. The experiment was arranged in a randomized block design with three replications. Sunflower seeds were soaked in solutions of 0, 10, 20, 30, and 40mmol $L^{-1}$ $C$ in the form of humic acids and then sown in the flower beds. At harvest, the flower stems were collected to determine the variables: stem height, stem diameter, fresh stem weight, number of leaves per stem, leaf fresh weight per stem, leaf dry matter per stem, number of flower stalks, and diameter of the floral receptacle. Data were subjected to regression analysis. The results showed increases in all variables in response to the application of humic acids, except in number of leaves per stem, which remained unchanged. The greatest increases usually resulted from concentrations from 15 to $20 \mathrm{mmol} L^{-1} C$ in the form of humic acid. It was concluded that the seed treatment with humic acid at the indicated concentrations increases the number and commercial quality of flower stalks of field-grown ornamental sunflower.
\end{abstract}

Key words: Helianthus annuus, cut flowers, humic substances.

\section{RESUMO}

Os ácidos húmicos, fração da matéria orgânica, apresentam efeitos estimulantes no crescimento e desenvolvimento de plantas ornamentais. O presente trabalho objetivou estudar o crescimento e produção de girassol ornamental (Helianthus annuus L.) em resposta à aplicação de ácidos húmicos em cultivo em campo. $O$ delineamento estatístico foi o de blocos casualizados com três repetições. As sementes foram imersas nas soluções de 0, 10, 20, 30 e 40mmol $L^{-1}$ de C na forma de ácidos húmicos e, posteriormente, semeadas em canteiros a campo. No momento da colheita, as hastes florais foram coletadas para medição das variáveis: altura da haste, diâmetro da haste, matéria fresca da haste, número de folhas por haste, matéria fresca foliar por haste, matéria seca foliar por haste, número de hastes florais e diâmetro do receptáculo floral. Os dados foram submetidos à análise de regressão. Os resultados mostraram incrementos em todas as variáveis analisadas, em resposta à aplicação de ácidos húmicos, com exceção do número de folhas por haste, que não sofreu alteração. Os maiores incrementos foram, em geral, proporcionados em concentrações entre 15 a $20 \mathrm{mmol}$ $L^{-1}$ de $C$ na forma de ácidos húmicos. Conclui-se que o uso dos ácidos húmicos nas concentrações indicadas aumenta o número e a qualidade comercial das hastes florais de girassol ornamental cultivado em campo.

Palavras-chave: Helianthus annuus, flores de corte, substâncias húmicas.

\section{INTRODUCTION}

The ornamental sunflower (Helianthus annuus L.) of the Asteraceae family is gaining importance on the flower and ornamental plant markets due to the beauty of its inflorescence, the possibility of arrangements in pots or as cut flowers for bouquets and flower arrangements (CORMENZANA, 2001). The expansion of the ornamental sunflower cultivation is also related to the ease of scheduling production and marketing, the short growing cycle and the adaptability of the plant to different environmental conditions (CURTI et al., 2010; 2012).

The productivity of ornamental sunflower is primarily evaluated by the plant height and commercial quality of inflorescences (NEVES et al., 2005). These variables are influenced by different factors, mainly soil and climatic conditions (CURTI et al., 2010), mineral nutrition (NEVES et al., 2005; SILVA et al., 2009; SILVA et al., 2013), quality of

\footnotetext{
IUniversidade Federal de Viçosa (UFV), Campus Florestal, Rodovia LMG 818, Km 06, 35690-000, Florestal, MG, Brasil. E-mail: lilian.estrela@ufv.br.*Corresponding author.
} 
irrigation water (MACIEL et al., 2012), presence of silicon in the substrate (CARVALHO et al., 2009), and the use of plant growth regulators (SABAGGH, 2008; MATEUS et al., 2009). In this context, the seed treatment with humic acids, substances that markedly influence the growth and development of ornamental plants (BALDOTTO et al., 2009; 2012; 2013), could be an alternative to increase yield and quality of ornamental sunflower.

Humic acids are one part of the organic matter, corresponding to the fraction of humic substances soluble in alkaline medium (GUERRA et al., 2008). Their application to cuttings of ornamental plants induces adventitious rooting in hibiscus (BALDOTTO et al., 2012), bulb sprouting and inflorescence production in gladioli (BALDOTTO et al., 2013) and chlorophyll synthesis and biomass accumulation in pineapple seedlings (BALDOTTO et al., 2009). The applied concentration and source of organic matter used for the extraction of humic acids are factors that influence their effect on the plant metabolism (BALDOTTO et al., 2009).

This study aimed to evaluate the growth and production of ornamental sunflower (Helianthus annuus L.) in response to the seed treatment with humic acids for field cultivation.

\section{MATERIAL AND METHODS}

The study was carried out in a participatory manner, on a family farm of flower and ornamental plant production, named Sítio Natividade, in the municipality of Florestal, Minas Gerais, and in the laboratory of the Department of Floriculture of the Universidade Federal de Viçosa, Campus Florestal (UFV-CAF) at $19^{\circ} 53^{\prime} 57^{\prime \prime} \mathrm{S}$ latitude and $44^{\circ} 26^{\prime} 38^{\prime \prime} \mathrm{W}$, at $780 \mathrm{~m}$ asl. The experiment was initiated on 27 April 2012 and harvested on June 13, 2012, at the time of the first cut of flower stalks of ornamental sunflower for regional marketing.

The experimental matrix consisted of the following study factors: five doses of humic acids $\left(0,10,20,30\right.$, and $\left.40 \mathrm{mmol} \mathrm{L}^{-1} \mathrm{C}\right)$ extracted from vermicompost. The non-application of humic acid (HA

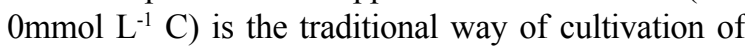
ornamental sunflower by the farmer. The humic acids were previously characterized by BALDOTTO et al. (2007). The seeds of ornamental sunflower(Helianthus annuus L.), cultivar Pollenless Sunbright (SAKATA, 2014), were soaked in solutions of the treatment for 24h (BALDOTTO et al., 2009) and the control was immersed in water. Thereafter, the seeds were sown in the soil, in an area of crop rotation with Gypsophila sp.
Limestone was applied to the entire area and N-P-K fertilizer 4-14-8 according to the chemical analysis of the soil and as recommended by RIBEIRO et al. (1999). Each bed was prepared with four 46m long rows and irrigated with a drip system. Each treatment consisted of a bed area with a length of $7 \mathrm{~m}$, with 4 crop rows, 11 seeds per meter, resulting in a total of 308 plants per plot. The experiment was conducted in a randomized block design with three replications.

The flower stalks were cut in the morning, when the inflorescences were fully developed and the ligulate flowers of the capitulum, closed, corresponding to the harvest stage for regional marketing in the municipality of Florestal. The flower stalks were assessed for the variables: stem height $(\mathrm{StH})$, with measuring tape; stem diameter (StD), measured in the middle third of the stem using a digital caliper (Starrett, model 727); stem fresh weight (StFW), measured on scales; number of leaves per stem (NLSt); leaf fresh weight per stem (LFWSt), weighed on scales; dry matter of leaves per stem (LDMSt), by oven-drying under forced air ventilation at $60^{\circ} \mathrm{C}$ for 5 days and subsequent weighing; number of flower stalks (NFSt); and diameter of the floral receptacle (DFR), measured with a caliper.

The results were subjected to regression analysis (ALVAREZ \& ALVAREZ, 2006). The choice of the selected model for each variable was based on the significance of the parameters and the $\mathrm{R}^{2}$ values (ALVAREZ \& ALVAREZ, 2006). The F test was used to test the regression coefficients at the same level of significance. The statistical program SAEG was used for data analysis. Regression equations were used to determine the concentrations of maximum physical efficiency (MPhE) for all studied characteristics. From these data, it was computed the values of the characteristics of ornamental sunflower for the humic acid concentrations inducing MPhE as well as the relative increase compared to the control $(\mathrm{RI}=$ relative increase, $100(\mathrm{x}-\mathrm{y}) / \mathrm{y}$, where $\mathrm{x}$ is the average value of the treatment with the highest value and $y$ the mean of the treatment with the lowest value).

\section{RESULTS AND DISCUSSION}

The results of the growth and yield analyses of ornamental sunflower plants in response to humic acid application showed differences in the number of flower stalks and their development (Table 1). The studied variables were positively influenced by the seed-treatment with humic acids, i.e., increases were recorded in comparison to conventional cultivation on the family farm (treatment without the application of humic acids, $\mathrm{AH} 0$ ).

Ciência Rural, v.45, n.5, mai, 2015. 
Table 1 - Mean values, coefficient of variation (CV) and regression equation for the characteristics stem height (StH), stem diameter (StD), stem fresh weight (StFW), number of leaves per stem (NLSt), leaf fresh weight per stem (LFWSt), leaf dry matter per stem (LDMSt), number of flower per stem (NFSt) and diameter of the floral receptacle (DFR) of ornamental sunflower plants in response to seed-treatment with humic acids (HA) at concentrations of $0,10,20,30$, and $40 \mathrm{mmol} \mathrm{L}^{-1} \mathrm{C}$. The non-application of humic acid (HA 0 ) is the traditional way of cultivation of ornamental sunflower by the farmer.

\begin{tabular}{|c|c|c|c|c|c|c|c|c|}
\hline \multirow{2}{*}{ Treat-ments } & \multirow[b]{2}{*}{$\mathrm{StH}$} & \multirow[b]{2}{*}{ StD } & \multirow[b]{2}{*}{ StFW } & \multirow[b]{2}{*}{ NLSt } & \multirow[b]{2}{*}{ LFWSt } & \multirow[b]{2}{*}{ LDMSt } & \multirow[b]{2}{*}{ NFSt } & \multirow[b]{2}{*}{ DFR } \\
\hline & & & & & & & & \\
\hline & $-\mathrm{cm}-$ & $-\mathrm{mm}-$ & $-\mathrm{g}-$ & & $-\mathrm{g}-$ & -g- & & $-\mathrm{mm}-$ \\
\hline HA 0 & 125.00 & 10.67 & 86.1 & 12 & 52.132 & 5.508 & 52 & 37.00 \\
\hline HA 10 & 138.33 & 12.00 & 118.1 & 11 & 47.712 & 7.131 & 67 & 49.00 \\
\hline HA 20 & 152.33 & 12.67 & 137.5 & 11 & 54.693 & 6.534 & 75 & 47.00 \\
\hline HA 30 & 120.00 & 11.33 & 129.2 & 11 & 53.287 & 6.217 & 74 & 44.67 \\
\hline HA 40 & 132.00 & 11.00 & 106.9 & 9 & 30.628 & 4.157 & 81 & 44.67 \\
\hline CV (\%) & 3.94 & 9.68 & 11.99 & 11.41 & 25.01 & 31.00 & 2.92 & 5.63 \\
\hline Variable & \multicolumn{6}{|c|}{ Regression equation } & \multicolumn{2}{|c|}{$\mathrm{R}^{2}$} \\
\hline $\mathrm{StH}(\mathrm{cm})$ & \multicolumn{6}{|c|}{$\mathrm{y}=123.03+4.4861 \mathrm{x}-0.2533 \mathrm{x}^{2}+0.0056^{(\mathrm{P}<0.28)} \mathrm{x}^{3}$} & \multicolumn{2}{|c|}{0.57} \\
\hline $\mathrm{StD}(\mathrm{mm})$ & \multicolumn{6}{|c|}{$y=10.771+0.1524 x-0.0038^{*} x^{2}$} & \multicolumn{2}{|c|}{0.79} \\
\hline $\mathrm{StFW}(\mathrm{g})$ & \multicolumn{6}{|c|}{$y=85.556+4.4167 x-0.0972^{* *} x^{2}$} & \multicolumn{2}{|c|}{0.99} \\
\hline NLSt & \multicolumn{6}{|c|}{$y=11.686+0.0162 x-0.0019^{(P<0.20)} x^{2}$} & \multicolumn{2}{|c|}{0.82} \\
\hline LFWSt $(g)$ & \multicolumn{6}{|c|}{$\mathrm{y}=48.768+0.9075 \mathrm{x}-0.032^{(\mathrm{P}<0.12)} \mathrm{x}^{2}$} & \multicolumn{2}{|c|}{0.73} \\
\hline LDMSt (g) & \multicolumn{6}{|c|}{$y=5.6201+0.1663 x-0.0051^{*} x^{2}$} & \multicolumn{2}{|c|}{0.94} \\
\hline NFSt & \multicolumn{6}{|c|}{$y=53.2+1.3833 x-0.0183^{\circ} x^{2}$} & \multicolumn{2}{|c|}{0.94} \\
\hline DFR (mm) & \multicolumn{6}{|c|}{$\mathrm{y}=38.79+0.8052 \mathrm{x}-0.0174^{\circ} \mathrm{x}^{2}$} & \multicolumn{2}{|c|}{0.66} \\
\hline
\end{tabular}

$* *,{ }^{\circ}{ }^{\circ}$ and $\mathrm{P}=$ significant at $1,5,10$, and $\mathrm{P} \%$ probability, respectively.

It is noteworthy that the phenotypic features of all collected flower stalks were consistent with the regional consumption standard and the flowers were marketed by the farmers after growth evaluations. According to CURTI et al. (2012), the flower stalks of ornamental sunflower are cut at the opening of the ligulate ray flowers, which may be completed after the cut, when the stalks are arranged in water-filled vases. Since this stage can vary according to the region, season, field or greenhouse cultivation, variety, distance from the consumer market, and the quality standards for each plant material, harvesting should follow region-specific recommendations (LAMAS, 2002).

The response curves of the application of increasing humic acid concentrations generally showed quadratic variation (Table 1). With these equations it was calculated the concentrations of maximum physical efficiency (MPhE) of all measured characteristics of ornamental sunflower and increments in relation to the control (Table 2).

One of the determinant characteristics of the quality of ornamental sunflower is the height of the flower stalks (NEVES et al., 2005; SLOAN \& HARKNESS, 2006), which increased by $22 \%$ over the control by the application of $15 \mathrm{mmol} \mathrm{L}^{-1} \mathrm{C}$ in the form of humic acids (Table 2). According to SAKATA (2014), the height of flower stalks of cultivar Pollenless
Sunbright varies from 100 to $150 \mathrm{~cm}$. In this study, the control plants had, on average, $125 \mathrm{~cm}$ high flowers, and with humic acid applications at the concentration

Table 2 - Concentration of maximum physical efficiency (MPhE), average control, average $\mathrm{MPhE}$, relative increase $(\mathrm{RI}=$ relative increase, $100(\mathrm{x}-\mathrm{y}) / \mathrm{y}$, where $\mathrm{x}$ is the average value of the treatment with the highest value and $y$ the mean of the treatment of lowest value) for the characteristics, stem height ( $\mathrm{StH})$, stem diameter (StD), fresh weight of stem (StFW), number of leaves per stem (NLSt), leaf fresh weight per stem (LFWSt), leaf dry matter per stem (LDMSt) number of flower stalks (NFSt) and diameter of the floral receptacle (DFR) of ornamental sunflower plants in response to seedtreatment with humic acid (HA) at concentrations of 0 , 10, 20,30, and 40mmol L $\mathrm{m}^{-1} \mathrm{C}$.

\begin{tabular}{lclll}
\hline Variable & $\begin{array}{c}\text { MPhE } \\
\text { concentration } \\
\text { (mmol L } \\
\text { of HA) }\end{array}$ & $\begin{array}{c}\text { MPhE } \\
\text { Mean }\end{array}$ & $\begin{array}{c}\text { Control } \\
\text { Mean }\end{array}$ & RI (\%) \\
\hline StH (cm) & 15.08 & 152.28 & 125.00 & 22 \\
StD (mm) & 20.05 & 12.30 & 10.67 & 15 \\
StFW (g) & 22.77 & 135.73 & 86.10 & 58 \\
NLSt & 4.26 & 12 & 12 & 0 \\
LFWSt (g) & 14.18 & 55.200 & 52.132 & 6 \\
LDMSt (g) & 16.30 & 6.980 & 5.508 & 27 \\
NFSt & 37.80 & 79 & 52 & 52 \\
DFR (mm) & 23.14 & 48.11 & 37.00 & 30 \\
\hline
\end{tabular}


of MPhE this height reached $152 \mathrm{~cm}$, increasing the quality of the product, since longer stems allow a greater diversification in the assembly of bouquets and flower arrangements. The height of the flower stalks of ornamental sunflower is determined, among several other factors, by the hormonal balance (SABBAGH, 2008). For potted sunflower plants, for example, it is known that the application of gibberellin inhibitors decreases the plant height by reducing the internode length (SABBAGH, 2008). To date, there are no reports in the literature that the seed treatment with humic acids would interfere with the endogenous concentration of gibberellins. However, studies show that one of the mechanisms of action of humic acids is the activation of $\mathrm{H}^{+}$-ATPases of cell membranes (ZANDONADI et al., 2007), similarly to the mechanism of action of the plant hormones of the auxin type. This mechanism is related to the theory of acid growth that postulates that the increase in proton extrusion induces the action of enzymes that act on the cell wall increasing its plasticity and, consequently, allowing cell elongation (RAYLE \& CLELAND, 1972).

Increases in the flower stalk diameter of approximately $2 \mathrm{~mm}$ by the application of humic acid concentrations of $20 \mathrm{mmol} \mathrm{L}^{-1} \mathrm{C}$ were observed (Table 2). A larger stem diameter $(12.30 \mathrm{~mm})$ contributes to decrease the lodging of flower stalks in the field and breaking in the post-harvest process, aside from favoring the support of larger inflorescences. NEVES et al. (2005) found that the ornamental sunflower plants grown in hydroponics also have a larger stem diameter $(13 \mathrm{~mm})$ than those grown in the conventional system $(8 \mathrm{~mm})$.

Fresh matter accumulation in flower stalks and dry matter accumulation in leaves were also favored by humic acid concentrations close to 20mmol L-1 C (Table 2). BALDOTTO et al. (2009; 2012; 2013) found that humic acid applications close to $20 \mathrm{mmol} \mathrm{L}^{-1} \mathrm{C}$ to gladiolus bulbs, pineapple seedlings and croton cuttings concentrations increased the biomass. The positive effects on the accumulation of shoot matter in humic acid treated sunflower plants can be explained by different physiological factors such as increased synthesis of chlorophyll (BALDOTTO et al., 2009), increased nutrient uptake (NARDI et al., 2002), growth promotion of the root system (BALDOTTO et al., 2011) and the formation of root hairs (SILVA et al., 2011).

The number of leaves per flower stem was not affected by application of humic acids (Table 2). For the cultivation of ornamental sunflowers as cut flower, a higher number of leaves per stem would be of no avail because this could increases costs in the post- harvest process, when the leaves are removed by hand for later sale of the stalks. It was also found that the fresh and dry weight of leaves per sunflower stem increased at humic acid concentrations inducing MPhE (Table 2), i.e, in humic-acid treated plants, the cumulativeefficiency of waterandnutrients was greater.

The flowers of ornamental sunflower not open at the same time, successive crops are necessary at the same cultivation in accordance with the flowers opening. This study was based on information obtained in the first cut for local marketing. It was observed that the number of flower stems collected in the first cut increased with the application of humic acids (Table 2), consequently there is a decreasing trend in the crop cycle of ornamental sunflower, which, according to the company SAKATA (2014) the cycle of the studied cultivar Pollenless Sunbright lasts approximately 60 to 70 days. Similar results were obtained by BALDOTTO et al. (2013) with gladioli, in which flowering was increased and anticipated by the application of humic acid extracted from humus.

The diameter of the floral receptacle of ornamental sunflower was influenced by the application of humic acid, with an increase of $30 \%$ at a humic acid concentration close to $20 \mathrm{mmol} \mathrm{L}^{-1} \mathrm{C}$ (Table 2). According to ROSSI (1998), the diameter of the capitulum, of the sunflower is influenced by the genotype and environmental conditions. The use of growth regulators (SABAGGH, 2008), mineral nutrition (NEVES et al., 2005; CARVALHO et al., 2009) and sowing date (CURTI, 2010) also influence the size of the inflorescence of ornamental sunflower.

The characteristics with the strongest influence on the marketing of ornamental sunflowers as cut flowers is the flower diameter and the length and diameter of the flower stalk (NEVES et al., 2005; SLOAN; HARKNESS, 2006). These properties were improved by the application of humic acids, particularly at $20 \mathrm{mmol} \mathrm{L}^{-1} \mathrm{C}$. These results suggest that humic acid used in commercial sunflower cultivation for cut flower can be a viable alternative to increase production and product quality.

It is worth emphasizing the participatory form of this study and the data generation within the production system. This way of conducting research facilitates the achievement and enriches the interpretation of results, since it is based on the participation of professionals (researchers and farmers) with different experiences. In addition, it ensures the rapid assimilation of information or products by the farmers, for being integrated in all experimental stages. 


\section{CONCLUSIONS}

The seed treatment of ornamental sunflower with humic acids increases the number and quality of the flower stems. The concentration range of humic acids that induces maximum efficiency in the production and quality of ornamental sunflower stalks is $15-20 \mathrm{mmol} \mathrm{L}^{-1} \mathrm{C}$.

\section{ACKNOWLEDGEMENTS}

The authors thank the farmer Solange Alves Soares Marra and her husband Edvar (Sítio Natividade) and Marcelino Alves Mendes (Empresa de Assistência Técnica e Extensão Rural, EMATER- Florestal, MG) for collaboration in the execution of work. Also thank Conselho Nacional de Desenvolvimento Científico e Tecnológico (CNPq Proc.470192/2013-5) and Fundação de Amparo à Pesquisa do Estado de Minas Gerais (FAPEMIG Proc.00450/13) for the financial support.

\section{REFERENCES}

ALVAREZ, V.V.H.; ALVAREZ, G.A.M. Comparações de médias ou testes de hipóteses? Contrastes! Boletim Informativo da Sociedade Brasileira de Ciência do Solo, v.31, p.24-34, 2006.

BALDOTTO, L.E.B. et al. Desempenho do abacaxizeiro 'Vitória' em resposta à aplicação de ácidos húmicos durante a aclimatação. Revista Brasileira de Ciência do Solo, v.33, n.4, p.979-990, 2009 Available from: $<$ http://www.scielo.br/scielo.php?script=sci arttex t\&pid $=$ S010006832009000400022\&lng $=$ pt\&nrm $=$ iso $>$. Accessed: Jan. 16, 2014. doi: 10.1590/S0100-06832009000400022.

BALDOTTO, L.E.B. et al. Adventitious rooting in cuttings of croton and hibiscus in response to indolbutyric acid and humic acid. Revista Ceres, v.59, n.4, p.476-483, 2012. Available from: $<$ http://www.scielo.br/scielo.php?script=sci_arttext\&pid=S0034737X2013000100020\&lng=pt\&nrm=iso $>$. Accessed: Jan. 16, 2014. doi: 10.1590/S0034-737X2013000100020.

BALDOTTO, M.A. et al. Propriedades redox e grupos funcionais de ácidos húmicos isolados de adubos orgânicos. Revista Brasileira de Ciência do Solo, v.31, n.3, p.465-475, 2007. Available from: $<$ http://www.scielo.br/scielo.php?script $=$ sci_arttext\&pid $=$ S0100 06832007000300006\&lng=pt\&nrm=iso $>$. Accessed: Jan. 16, 2014. doi: 10.1590/S0100-06832007000300006.

BALDOTTO, M.A. et al. Root growth of Arabidopsis thaliana (L.) Heynh. treated with humic acids isolated from typical soils of Rio de Janeiro state, Brazil. Revista Ceres, v.58, n.4, p.504-511, 2011. Available from: <http:/www.scielo.br/scielo. php?script $=$ sci_arttext\&pid=S0034737X2011000400015\&lng $=$ pt\&nrm $=$ iso $>$. Accessed: Jan. 16, 2014. doi: 10.1590/S0034$737 \mathrm{X} 2011000400015$.

BALDOTTO, M.A. et al. Gladiolus development in response to bulb treatment with different concentrations of humic acids. Revista Ceres, v.60, n.1, p.138-142, 2013. Available from: <http:// www.scielo.br/scielo.php?script $=$ sci_arttext\&pid=S0034737X20 13000100020\&lng=pt\&nrm=iso >. Accessed: Jan. 16, 2014. doi: $10.1590 / \mathrm{S} 0034-737 \mathrm{X} 2013000100020$

CARVALHO, M.P. et al. Silício melhora produção e qualidade do girassol ornamental em vaso. Ciência Rural, v.39, n.8, p.2394-2399, 2009. Available from: <http://www.scielo.br/scielo php?script $=$ sci_arttext\&pid=S010384782009000800019\&lng $=$ pt\&nrm=iso\&tlng=en>. Accessed: Jan. 16, 2014. doi: 10.1590/ S0103-84782009005000194

CORMENZANA, J.M.A. El cultivo de girasol (Helianthus annuus) para flor cortada. Flormarket, n.2, p.55-61, 2001. Available from: $<$ http://www.bio-nica.info/biblioteca/Melgares\%202001\%20 girasol.PDF>. Accessed: Jan. 16, 2014.

CURTI, G.L. Caracterização de cultivares de girassol ornamental semeados em diferentes épocas no oeste catarinense. 2010. $75 \mathrm{f}$. Dissertação (Mestrado em Agronomia) - Campus Pato Branco, Universidade Tecnológica Federal do Paraná, Pato Branco, PR.

CURTI, G.L. et al. Girassol ornamental: caracterização, pós-colheita e escala de senescência. Revista de Ciências Agrárias, v.35, n.23, p.240-250, 2012. Available from: <http://www.scielo.gpeari. mctes.pt/pdf/rca/v35n1/v35n1a23.pdf>. Accessed: Jan. 16, 2014.

GUERRA, J.C.M. et al. Macromoléculas e substâncias húmicas. In: SANTOS, G.A. (Ed.). Fundamentos da matéria orgânica do solo: ecossistemas tropicais \& subtropicais. 2.ed. Porto Alegre: Metrópole, 2008. p.19-26

LAMAS, A.M. Floricultura tropical: técnicas de cultivo. Recife: SEBRAE-PE, 2002. 87p. Available from: $<$ http://www.fit.ufsc.br/ disciplinas_download.php?cod=2113>. Accessed: Jan.16, 2014

MACIEL, M.P. et al. Produção de girassol ornamental com uso de águas salobras em sistema hidropônico NFT. Revista Brasileira de Engenharia Agrícola e Ambiental, v.16, n.2, p.165-172, 2012. Available from: $<$ http://www.scielo.br/scielo.php?script=sci_ar ttext\&pid $=\mathrm{S} 141543662012000200006 \& \operatorname{lng}=\mathrm{en} \& \mathrm{nrm}=\mathrm{iso}>$. Accessed: Jan.16, 2014. doi: 10.1590/S1415-43662012000200006.

MATEUS, C.M.D. et al. Estratégias para redução do porte de girassol ornamental para comercialização em vaso. Bragantia, v.68, n.3, p.681-687, 2009. Available from: $<$ http://www.scielo.br/ scielo.php?script $=$ sci_arttext\&pid $=$ S000687052009000300015\&1 ng=en\&nrm=iso $>$. Accessed: Jan. 16, 2014. doi: 10.1590/S000687052009000300015

NARDI, S. et al. Physiological effects of humic substances on higher plants. Soil Biology and Biochemistry, v.34, p.1527-1536, 2002. Available from: $<$ http://www.humateproducts.com/images/ Physiological_effects_of_humic_substances_on_higher_plants. pdf>. Accessed: Jan. 16, 2014

NEVES, M.B. et al. Desenvolvimento de plantas de girassol ornamental (Helianthus annuus L.) em vasos, em dois substratos com solução nutritiva e em solo. Científica, v.33, n.2, p.127-133, 2005. Available from: <http://www.cientifica.org.br/index.php/ cientifica/article/view/41/24>. Accessed: Jan. 16, 2014.

RAYLE,D.L.;CLELANDR.etal.Thein-vitroacid-growthresponserelation to in-vivo growth responses and auxin action. Planta, v.104, p.282-296, 1972. Available from: <http://link.springer. com/article/10.1007/BF00386312>. Accessed: Jan. 16, 2014.

ROSSI, R. O girassol. Curitiba: Tecnoagro, 1998. 333p.

RIBEIRO, A.C. et al. Recomendações para o uso de corretivos e fertilizantes em Minas Gerais. 5.aprox. Viçosa: UFV, 1999. 359p.

SABAGGH, M.C. Redução de porte de girassol ornamental pela aplicação de reguladores vegetais. 2008. 77f. Dissertação (Mestrado em Ciências) - Setor de Ciências Agrárias, Universidade Federal do Paraná, Curitiba, PR. 
SAKATA. Flores de corte - Sunflower F1. Acessed: Jan. 16, 2014. Online. Available from: <http://www.sakata.com.br/cas/ productos/flores-de-corte/sunflower-f1>.

SILVA, A.C. et al. Promoção do crescimento radicular de plântulas de tomateiro por substâncias húmicas isoladas de turfeiras. Revista Brasileira de Ciência do Solo, v.35, p.1609-1617, 2011. Available from: $<$ http://www.scielo.br/scielo.php?script=sci_arttext\&pid=S 010006832011000500015\&lng=en\&nrm=iso > . Accessed: Jan. 16, 2014. doi: 10.1590/S0100-06832011000500015.

SILVA, E.A. et al. Utilização de adubos de liberação lenta na produção de mudas de Helianthus annuus L. cv. Sunbright Supreme. Thesis, n.19, p.82-91, 2013. Available from: $<$ http://www cantareira.br/thesis2/ed_19/art6.pdf >. Accessed: Jan. 16, 2014.
SILVA, T.G.F. et al. Crescimento do girassol ornamental cultivado em ambiente protegido sob diferentes níveis de condutividade elétrica de fertirrigação. Revista Ceres, v.56, n.5, p.602-610, 2009. Available from: <http://www.ceres.ufv.br/ceres/revistas/ V56N005P16208.pdf>. Accessed: Jan. 16, 2014

SLOAN, R.C.; HARKNESS, S.S. Field evaluation of pollenfree sunflower cultivars for cut flower production. HortTechnology, v.16, n.2, p.324-327, 2006. Available from: <http://horttech.ashspublications. org/content/16/2/324.full.pdf +html>. Accessed: Jan. 16, 2014.

ZANDONADI, D.B. et al. Indolacetic and humic acids induce lateral root development through a concerted plasmalemma and tonoplast $\mathrm{H}^{+}$pumps activation. Planta, v.225, n.6, p.1583-1595, 2007. Available from: <http://link.springer.com/article/10.1007/ s00425-006-0454-2/fulltext.html $>$. Accessed: Jan. 16, 2014. doi: $10.1007 / \mathrm{s} 00425-006-0454-2$. 